\title{
Europe - from common market to political union
}

Heide Simonis

Correspondence: Tokio70@web.de State of Schleswig-Holstein, Schillerstr. 12, D-24116 Kiel, Germany

\begin{abstract}
s
This article is about the evolution of Europe after the Second World War from a Union for coal and steel to a common market and a political union, the European Union with a common currency - the Euro. The ups and down of the process of economic and social integration are addressed, as well as the possible ways towards the future. This future could either mean a new treaty from above or a better founding from the bottom. The Nobel Peace Prize for the European Union is supposed to be a burden but also a stimulus for further political integration and sustainable development.

Dieser Artikel behandelt die Europas nach dem Zweiten Weltkrieg von einer Gemeinschaft für Kohle und Stahl zu einem gemeinsamen Markt und einer politischen Union mit einer gemeinsamen Währung - dem Euro. Die Aufs und Abs der ökonomischen und sozialen Integration werden angesprochen, ebenso wie die möglichen Wege in die Zukunft. Die Zukunft könnte entweder einen neuen Vertrag von oben oder besser eine Grundlegung von unten bedeuten. Der Friedensnobelpreis für die Europäische Union mag sowohl eine Bürde aber auch eine Ermunterung für weitere politische Integration sowie nachhaltige Entwicklung sein.
\end{abstract}

Keywords: Second world war damages, Restructuring the economy, European coal and steel commuity, European political union, Common currency Euro, The future EU: treaty amendment or treaty re-founding, The Nobel Peace Prize 2012

\section{Europe in crisis?}

Recent discussions about the European Union (EU) have not been a source of much delight: too top-heavy, bureaucratic, expensive and inefficient, to name but a few of the popular mental objections associated with the word Europe. For many citizens, the European Union also appears to be too distant to be able to grasp their everyday problems, let alone resolve them. With such a mood prevailing, Europe is perceived by many to be more of an encumbrance, a dictation, a cost factor ... rather than a model case.

By contrast, however, there are a great many positive concrete facts that have to do with Europe: equal rights for men and women, freedom of movement and establishment, tariff elimination, effective environmental protection and innovative energy policy - to name just a few of the main achievements.

Such inconsistent perceptions and assessments all too easily lead to the desire to attempt to redefine the European Union: to halt or roll back integration, to abolish the

(C) 2016 Simonis. Open Access This article is distributed under the terms of the Creative Commons Attribution 4.0 International License (http://creativecommons.org/licenses/by/4.0/), which permits unrestricted use, distribution, and reproduction in any medium, provided you give appropriate credit to the original author(s) and the source, provide a link to the Creative Commons license, and indicate if changes were made. 
new currency - the Euro - and to seek solutions in old nationalist formulas rather than in new European initiatives.

It is correct to say, that the euphoria felt in the early years of the European Union has evaporated in the wake of the continuing financial and debt crisis, and that a number of tensions and irritations have evolved. However, it would be wrong now to revoke the Union or even exit the Euro monetary system. After all, a political union and a common currency cannot simply be replaced like a soiled shirt.

If there are faults in the construction of the economic and monetary union and if errors of management were made, then the construction needs to be corrected and management rules changed. And if there is massive speculation against the Euro, then such speculation must be stopped. This has been happening for some time and some progress has been made or is about to be achieved - for example, banking supervision and the financial transaction tax.

And yet another issue is also of relevance. In the course of the protracted debate on the crisis, fuelled anew from day to day, many Europeans appear to have forgotten what changes the European Union have brought about in the past, and what it therefore means in structural terms. It has created and repeatedly confirmed fundamental values - above all, peace, freedom, tolerance and solidarity.

After long disputes and an infinite number of armed conflicts, the peoples of Europe have become reconciled, and now live in peace. Dictatorships have become democracies. In the context of ever-increasing integration and the eastward enlargement of the European Union (the EU 27), the Europeans have created a parliamentary system - featuring a Council, a Commission and a Parliament. They have generated historically unparalleled wealth, and endeavour to distribute this wealth fairly by adopting and implementing Europe-wide structural policies. They help each other to compensate for excessively disparate living conditions. Thus assistance is also provided - in alliance with the International Monetary Fund - to those countries that have run into financial difficulties, above all Greece, at present.

A part of these financial mechanisms and compensation payments is permanently built into the system of the European Union, while additional benefits must be negotiated and agreed upon institutionally each time - as was recently the case with the European Stability Mechanism (ESM), which became operational at the beginning of October 2012.

In the face of the current financial difficulties, it is sometimes argued that "Europe has lost its compass". Indeed, there are massive conflicts of interest and anxieties about the future, not only in crisis-torn Greece. However, modern Europe is also built on strong foundations - and there are also clear signposts for the future.

\section{On the history of European values}

It is important to remember how the new Europe evolved from the wasteland left behind by the Nazis. In almost all respects, World War II was more terrible than any other armed conflict experienced in previous centuries. It claimed over 60 million lives. More than 60 countries were directly or indirectly involved in the war. 110 million people were under arms. There was the Holocaust of the Jews in Europe. And there were unspeakable war crimes. There was area bombing of cities and municipalities, which were completely destroyed.... 
Europe's decline began with the German army's invasion of Poland on 1 September 1939. Although international bodies such as the Inter-Parliamentary Union (IPU) and the League of Nations were tasked with identifying negative developments and preserving peace, national egoisms were stronger than the understanding to resist these forces together. German warfare was designed for extensive conquests. Virtually the whole of Europe was occupied by the German troupes, the conquered countries were exploited, opposition suppressed, and resistance crushed with brute force. Millions of Jewish citizens of Germany and other European countries were murdered. The aim of German policy at that time was to create a Grand German Empire, at any price. War spread across the world like anthrax, not only in Europe, but also in Asia and the Pacific.

The horrific nightmare came to an end at last in May 1945. Europe was completely devastated. People were starving, undernourished and undersupplied. Germany had made itself an outcast. All other Europeans agreed on one point: this country should never again be strong enough to wage war and invade others; all respect for the country had been lost. The Morgenthau Plan was drawn up to ensure the complete deindustrialisation of Germany.

Since, however, the alliance of convenience between the USA and the Soviet Union soon broke down due to their different visions on the future development of Europe, Germany was brought back into the fold of European countries sooner than most had expected.

However, affection for Germany was not the focus of these political considerations, but the wish to reconstruct the economy of Europe as quickly as possible with the help of the "Marshall Plan". For which Germany was needed. The Germans recognised this opportunity offered to them as a possibility to look to the future. Thus they quickly became well-behaved, financially strong, punctual Europeans. They shouldered more than their burden, without gaining love or praise in the process. They demonstrated their appreciation with discipline, economic performance, great diligence, political dependence and support in Western alliances. Often, however, mixed with a pinch of contempt for what they considered to be the lazier Southern Europeans.

Then again, in view of their culpable history, they would never have considered not accepting the position of net contributor in Europe - the "paymaster". On the contrary: the Federal Republic of Germany bought itself out of virtually all difficult situations, often simply paying up rather than truly becoming involved, reinforcing the general perception that it had financial clout.

In the meantime, however, quite a few Germans would be pleased to see the back of the European "paymaster" label, which soon evolved. Those who grew up in the age of European Interrail, school exchanges and school trips to other European countries seem to think that stories of boundary posts, visa regimes and passport controls are exaggerated or "from the old days", although they stem from a not too distant past.

Be that as it may, today's young generation of Germans does not readily derive from this the necessity to bear a heavy financial burden for Europe. And many older German citizens expect an answer to the question of why they should have to pay for the economic and fiscal errors of some of their neighbours in the form of cuts to their own social security systems. One established opinion is "We bend over backwards while others enjoy themselves." For this reason, the necessary European solidarity must be re-explained and fought for again and again. 
But how can Europe (the European Union) be made into a topic that is more than the sum of all small or large transfer payments? How can we manage to show that a functioning, stable Europe is not just a first civic responsibility, but the foundation for a peaceful coexistence in the future - with the resulting positive effects for the economy, for society and the environment?

What, therefore, are the ways out of the current European crisis - and the Euro debate?

\section{Ways out of the crisis}

Two theoretical models of tomorrow's Europe are competing with each other: Treaty amendment or treaty re-founding - "change from the top down" or "better founding from the bottom up".

Many advocates of Europe insist on the importance of bringing the European states still closer together, particularly calling for common fiscal policy. This is based on the opinion that a new Europe is a question of its external organisation - featuring a parliament with greater powers, a more effective European Commission, and a European President elected directly by the peoples of Europe (and not by their governments).

But the question remains whether or not the Europeans would love such a construct. Then there is the question of whether the multiple national identities could be "resolved from the top down", without concern for the people's attachment to their region, their language, their history. After all, many (most?) Europeans continue to be, first and foremost, French, British, Italian, Spanish, German, Polish, and so on. A centralised Treaty amendment - a "Europe from the top down" - is difficult due to the prevalence of such multiple identities and, if pursued too rapidly and clumsily, could easily turn into overt opposition.

Most Europeans are even less happy about the fact that certain members of the elite are quite familiar with the (much too complicated) European arrangements and instruments, and exploit them to their advantage, while they - the majority - have to assume responsibility for the misdeeds of banks and loan sharks. Allegiance to Europe may also flounder over this issue.

Neither the flag of Europe nor a European anthem, neither the European Parliament nor the European Commission can really convince the populace when unemployment is rising and pay and pensions are falling, due to inadequate political structures or fiscal and monetary mismanagement. Good policy and good management - these issues represent the need of the moment.

The increasing violence at demonstrations experienced recently is indicative of the fact that the boiler is at risk of exploding in many countries, and possibly even throughout Europe. It seems we are paying the price for the fact that the "Europeanisation of politics" in Europe did not go far enough and that the way Europe Union functions continues to be not yet sufficiently understood. We are also paying the price for the fact that, in the initial phase of the European Parliament and the European Commission, politicians were often nominated along the lines of "Hast Du einen Opa, schick ihn nach Europa" (when you have a grandpa, send him to Europa) - a derisory saying suggesting the poor quality of the average European Parliament member.

Some may consider the Europeans' divergent views on the demands placed on the European Parliament and the European Commission to be less important (a historical 
triviality). And yet, to this day, they impede rapid intervention and qualified decisionmaking when things get serious or when push comes to shove. Particularly bearing in mind the very different mentalities and realities in Europe: the City of London happens to march to a different beat than the Old Town of Athens or the Centre of Prague. Particularly, Scandinavian pragmatism looks at the over-regulation engaged in by Brussels with distrust.

If these structural divergences are to be included in the future design process of active European parliamentarianism and a competent Commission, then the "homework" imposed on the Europeans by the Treaty of Lisbon will have to be tackled at long last. This means, among other things: introducing the subsidiarity principle wherever possible; determining what can be achieved equally well, or even better, on the next level down. This would be an important part of what can alternatively or additionally be called the "re-founding of Europe" - a better founding from the bottom up.

\section{On Germany's role in Europe}

The role of the "paymaster and taskmaster" appeals to most Germans in that they believe they are better equipped with the virtues described than other Europeans. The Germans, however, are not Europe's role model - and they must not want to be so. The German history does not permit this. With its large share of the European Structural Funds and the financial leverage of the "Troika", however, Germany is directly or indirectly imposing on its European neighbours practices (such as the "austerity budgets") that would not survive politically at home.

The recklessness with which several duellists (among them German professors) promote an "Exit from the Euro", which would supposedly resolve all of the problems, is simultaneously remarkable and dangerous in view of the harsh economic realities. A return to the Deutschmark would signify a $40 \%$ appreciation of the currency for Germany, which would have a tremendous impact on its export-led economy - resulting in high rates of unemployment and considerable tax losses. More fitting visions of the future exist. This is disconnected from the question of whether the Euro, which, historically speaking, was one of the conditions for German reunification, could be "toppled" at all by Germany.

\section{European guarantees}

As a matter of principle, the European Union guarantees its citizens political, civil and social rights. Passports no longer need to be shown. Citizens have the right to information. They have access to all European labour markets, to political participation at local level, and to participation in the social security systems. Whether all of this is viewed as a blessing and as the fundamental democratisation of Europe to guarantee freedom and prosperity depends on whether Europe's citizens understand and accept this "invitation" to social integration accordingly.

A recent empirical study has revealed that highly skilled university-educated specialists benefit more from these categories than the middle classes and people with lower skill levels. This can easily lead to arrogance and group egoisms that may damage the idea of Europe. Every group that benefits from Europe to a greater extent than others may be less prepared to advocate future European integration. 
One important task is therefore to maintain a high degree of internal integration. But similar considerations apply to external integration.

It is easy to forget that an export-driven economy such as that of Europe must have a strong interest in ensuring that its trading partners and customers in other parts of the world prosper too. Those who favour stringent austerity measures will change financial flows and, consequently, effective demand. Until now, Europe was a relatively open part of the global economy and the world markets. In times of crisis, it may not remain as such if national egoisms tend to grow. The creative task in overcoming the current crisis therefore is to design and establish a Europe which is open to the world.

\section{Review and preview}

Many observers in America and Asia no longer view Europe as a global powerhouse, as an economic and political challenge that generates innovative ideas and special accomplishments. How can this be possible, considering the fact that is was much more difficult to bring the divided peoples of Europe closer together after all those dreadful events of the past?

The founding fathers of the new Europe developed the basic idea of interlinking the economies of the nation-states to such an extent that a system of interdependency arose which would either work for the benefit of all or to the detriment of all, should collaboration fail.

This basic idea helped to establish the "European Coal and Steel Community" (ECSC) of 1952. At that time, coal and steel were the main means of production to get the civil economy moving again. Ensuring the effective control of the production and consumption of coal and steel was of utmost importance. It was easy for the socialist parties to give their consent, while the parties on the right of the political spectrum found it difficult to agree. Yet, the national governments gave up their historical sovereign rights, thus creating the first strong basis for the Union.

How do matters stand with such principles and strategies in Europe today? There is a great danger that politicians will gain approval if they claim to have "fought tooth and nail to defend national interests." In order to secure and assert their power within the regional and national framework, victories or defeats in Europe are often transformed into trophies. Nobody will want to say that all possibilities of European cooperation had already been achieved with the "European Coal and Steel Community" - but it did indeed achieve a great deal. Europe was never intended to be a construct in which all cucumbers must have an identical radius of curvature - to give just one example of many European policy absurdities that have occurred over the years. Nor was the European Union intended to be an institution in which the banks are permitted to play the role of the villain at the citizens' expense.

In other words: the European Union was never simply a mere economic community. It was about a wide range of other values - above all, peace and freedom; shared social and labour standards; integration and solidarity; mutual respect and appreciation. It was also, albeit somewhat belatedly, about environmental and climate protection. And then, following the spectacular start in Rio de Janeiro in 1992, it has been - and will continue to be - about sustainable development. 
Which takes me to my conclusion: I wish the Europe of my dreams a wide range of sustained values - a future based on peace and social balance, on economic prosperity and the protection of nature.

\section{Postscript}

The award of the Nobel Peace Prize to the European Union in 2012 would have been worth exploring in a separate lecture. I wrote this text before this award became known or was foreseeable in view of the contentious debate in and about Europe in recent years. Consequently, I shall simply close by making a comment on the Nobel Peace Prize.

Following the announcement of the award by the Nobel Prize Committee on 12 October 2012, José Manuel Barroso, President of the European Commission, stated: "The award is a very important message to Europe: the European Union is something very precious, that we should cherish for the good of the Europeans and for the good of the entire world."

No doubt, the Nobel Prize raises the standard concerning the expectations placed on the future development of Europe even higher. A major award can be a major burden. But a major award can also be an incentive. The Nobel Prize is not only a recognition of past achievements, it is also an encouragement to push ahead with the European project.

\section{Further reading}

Beck, Ulrich. 2012. Das deutsche Europa. Neue Machtlandschaften im Zeichen der Krise. Frankfurt am Main. Habermas, Jürgen. 2011. Zur Verfassung Europas. Ein Essay. Frankfurt am Main.

Acknowledgments

The author would like to thank Mrs. Teresa Gehrs for translating the text of the lecture from German into English.

Competing interests

The author declares he/she has no competing interests.

Received: 29 January 2016 Accepted: 16 February 2016

Published online: 25 May 2016

\section{Submit your manuscript to a SpringerOpen ${ }^{\circ}$ journal and benefit from:}

- Convenient online submission

- Rigorous peer review

- Immediate publication on acceptance

- Open access: articles freely available online

- High visibility within the field

- Retaining the copyright to your article

Submit your next manuscript at $>$ springeropen.com 